\title{
Review \\ Methods to Produce Nicotinic Acid with Potential Industrial Applications
}

\author{
Dawid Lisicki *D, Kinga Nowak and Beata Orlińska
}

Department of Organic Chemical Technology and Petrochemistry, Silesian University of Technology, Krzywoustego 4, 44-100 Gliwice, Poland; kingnow614@student.polsl.pl (K.N.); beata.orlinska@polsl.pl (B.O.)

* Correspondence: dawid.lisicki@polsl.pl; Tel.: +48-509-609-765

check for

updates

Citation: Lisicki, D.; Nowak, K.; Orlińska, B. Methods to Produce Nicotinic Acid with Potential Industrial Applications. Materials 2022, 15, 765. https://doi.org/ $10.3390 / \mathrm{ma} 15030765$

Academic Editor: Aivaras Kareiva

Received: 13 December 2021

Accepted: 14 January 2022

Published: 20 January 2022

Publisher's Note: MDPI stays neutral with regard to jurisdictional claims in published maps and institutional affiliations.

Copyright: (C) 2022 by the authors. Licensee MDPI, Basel, Switzerland. This article is an open access article distributed under the terms and conditions of the Creative Commons Attribution (CC BY) license (https:// creativecommons.org/licenses/by/ $4.0 /)$.

\begin{abstract}
Nicotinic acid is a naturally occurring pyridine carboxylic acid, contained in vitamin PP, an essential nutrient for humans and animals, and used as an antipelagic agent. Nicotinic acid can be made from tryptophan by plants and animals but is usually not completely bioavailable. Industrially, nicotinic acid is produced mainly by oxidation of 5-ethyl-2-methylpyridine with nitric acid. One of the by-products of the process is nitrous oxide, a gas that is difficult to recycle and manage, with a greenhouse effect 300 times stronger than $\mathrm{CO}_{2}$. A new technology for the industrial production of nicotinic acid is undoubtedly necessary to meet the needs of green chemistry and not burden the environment. We carried out a literature review on ecological methods to produce nicotinic acid from commercially available raw materials such as 3-methylpyridine and 5-ethyl-2-methylpyridine, especially focusing on those methods with potential industrial applications.
\end{abstract}

Keywords: nicotinic acid; oxidation; picoline; green chemistry; industrial synthesis

\section{Introduction}

The world produced 34,000 t of nicotinic acid (NA) in 2014, 63\% of which was intended as a feed additive, $22 \%$ as a food additive and for pharmaceutical use, and $15 \%$ for industrial applications [1]. On an industrial scale, 90\% of NA is produced synthetically from 3methylpyridine or 5-ethyl-2-methylpyridine. The global market size for NA was valued at USD 614 million in 2019 [2], and the largest NA producers are Lonza (18,000 t/y) and Vanetta $(6000 \mathrm{t} / \mathrm{y})$ [1].

NA is an essential nutrient for humans and helps reduce fatigue and maintain healthy skin, efficient metabolism, and mental health. The symptoms of NA deficiency are referred to as the "three D" diseases, dermatitis, diarrhea, and dementia. At the beginning of the 20th century, it was discovered that NA had a healing effect on pellagra, a disease of the skin, gastrointestinal tract, and nervous system [1]. Additionally, NA is essential for the life of animals under stress with disturbed intestinal microflora, especially farm animals, and NA deficiency leads to health problems and impairs animal reproduction and growth. For this reason, more than $60 \%$ of produced NA is used as an additive to food for poultry, pigs, fish, or domestic animals. In line with this health trend, you can find NA-enriched food products for humans, such as bread, flour, other grain products, and multivitamin drinks.

NA is available in the form of an extended-release prescription drug with the trade name Niaspan to treat hyperlipidemia and hypertriglyceridemia [3]. NA is also sold in the form of dietary supplements and mixtures for the prevention of venous insufficiency [4], leukemia [5], heart disease and anemia [6], atherosclerosis [7], insulin resistance [8], diabetic nephropathy [9], peptic ulcer disease [10], Alzheimer's disease [11], Parkinson's disease [12], or neoplastic diseases $[13,14]$. Modern preparations can be found such as cheek foils containing NA as the active substance [15]. NA has a potential anti-inflammatory and analgesic effect [16], and in dermatology, NA is used to treat acne vulgaris and rosacea [17] and is a popular ingredient in cosmetics to care for the skin and hair $[18,19]$.

In industry, NA is used: 
(1) In electroplating plants for tin plating in a sulphate bath, as well as for silvering and other electroplating applications [20,21];

(2) As an anticorrosion agent for mild steel [22];

(3) In chemical polishing of steel under high-temperature conditions;

(4) For the recovery of silver from the melting of slag [23,24];

(5) As a chemical imaging toner based on organic silver salts $[25,26]$;

(6) As a fungicide $[25,26]$;

(7) As an organic catalyst, including in the Hantzch reaction for the synthesis of 1,4dihydropyridine and polyhydroquinoline derivatives [27], quinazoline [28], and 1,2,4-selenadiazoles and thiazoles under aerobic conditions [29];

(8) In the preparation of heterogenized silica-based catalysts (SBA-NA) [30] or the magnetically modified $\mathrm{F}_{3} \mathrm{O}_{4} @ \mathrm{NA}$ catalyst [31];

(9) As a chelating agent in the production of VIB and VIII metal catalysts for hy- drocracking [32].

NA undergoes reactions typical for carboxylic acids and forms appropriate amides, esters, thioesters, acid halides, anhydrides, and salts. NA is also reduced to aldehyde or alcohol and hydrogenated to nipecotic acid, and it can form ionic liquids.

This paper aims to present a review on ecological methods to produce nicotinic acid from commercially available raw materials such as 3-methylpyridine and 5-ethyl-2methylpyridine, especially focusing on those methods with potential industrial applications. First, historical methods using stoichiometric oxidizing agents as well as industrial methods of producing NA, by oxidizing 5-ethyl-2-methylpyridine with nitric acid (V), and oxidizing ammonolysis of 3-picoline, are reported. Then, new methods of obtaining NA from 3picoline by liquid- and gas-phase oxidation are reviewed.

\section{Historical Methods of Producing NA}

Historically, NA production consisted of the oxidation of (((S)-3-[2-(N-methylpyrrolidine)] pyridine), quinoline, or 3-methylpyridine with stoichiometric oxidizing agents, such as $\mathrm{KMnO}_{4}, \mathrm{MnO}_{2}$, or $\mathrm{HClO}_{4}$ (Figure 1) [33-36]. Oxidation with $\mathrm{CrO}_{3}$ was not commercially implemented due to the high raw material cost, which requires up to 9 tons of $\mathrm{CrO}_{3}$ to obtain 1 ton of NA, and the carcinogenic effect of the oxidizing agent [37], which precluded use as a feed additive or in food or pharmacy [33]. Furthermore, the method using $\mathrm{CrO}_{3}$ produces a significant amount of inorganic waste, and the process has a low atom economy ((molecular weight of the product/total molecular weight of the substrates $) \times 100 \%)$ of $10 \%$.

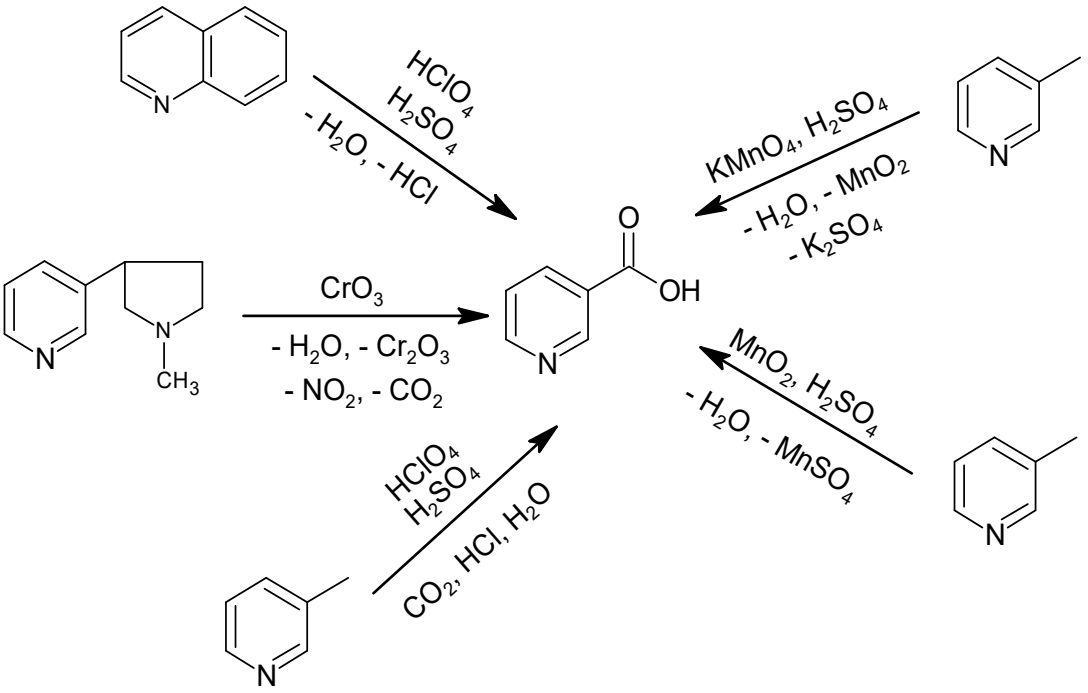

Figure 1. Historical methods for NA production. 
The process using $\mathrm{KMnO}_{4}$, in the presence of $\mathrm{H}_{2} \mathrm{SO}_{4}$ at $70-90{ }^{\circ} \mathrm{C}$ for $6 \mathrm{~h}$, produced NA with 77\% efficiency; however, it has only been practiced on a laboratory scale [35,38]. The improved method described in a DuPont patent used $\mathrm{MnO}_{2}$, also in the presence of $\mathrm{H}_{2} \mathrm{SO}_{4}$, but at $130{ }^{\circ} \mathrm{C}$ and a pressure of $0.1 \mathrm{MPa}$ for 3-6 h, with $75 \%$ efficiency [39]. Both methods are highly wasteful, require multiple processes and unit operations to obtain NA, and have a low atom economy of $21 \%$. Allied Dye and Chemical Corporation patented a method to obtain NA by oxidizing 3-methylpyridine or quinoline with $\mathrm{HClO}_{4}$ in the presence of $\mathrm{H}_{2} \mathrm{SO}_{4}$ and with the use of a catalyst in the form of selenium oxide or metallic selenium, preferably in the presence of bromides [34]. The oxidation of 3-methylpyridine was carried out at $250-320^{\circ} \mathrm{C}$ under atmospheric pressure for $15 \mathrm{~min}$, yielding NA with $50 \%$ efficiency. Quinoline oxidation was carried out at $150-190{ }^{\circ} \mathrm{C}$ for $30 \mathrm{~min}$ and then at $320^{\circ} \mathrm{C}$ for another $30 \mathrm{~min}$ to decarboxylate the quinolinic acid intermediate to NA, with an efficiency of $82 \%$ [34]. These methods produce a significant amount of waste, including $\mathrm{HCl}$, use a dangerous oxidizing agent, $\mathrm{HClO}_{4}$, and have a relatively low atom economy of $73 \%$.

The literature also describes methods to oxidize nicotine, 3-methylpyridine, and quinoline with $\mathrm{H}_{2} \mathrm{SO}_{4}$ in the presence of metal catalysts [36]. By oxidizing nicotine in the range of $230-320{ }^{\circ} \mathrm{C}$ for $25-225 \mathrm{~min}$, the highest efficiency for NA production was $77 \%$ and was obtained using metallic selenium, whereas the use of $\mathrm{HgSO}_{4}, \mathrm{Bi}\left(\mathrm{NO}_{3}\right)_{3}$, or $\mathrm{CuSeO}$ catalysts yielded maximum efficiencies of $46 \%, 34 \%$, or $39 \%$, respectively. The oxidation of 3-methylpyridine at $260-320^{\circ} \mathrm{C}$ for 55-235 min using selenium metal as the catalyst resulted in a maximum yield of $51 \%$, while $\mathrm{HgSO}_{4}$ allowed for only a $38 \%$ yield. Quinoline oxidation was carried out at $240-320^{\circ} \mathrm{C}$ for $35-55 \mathrm{~min}$ and with a metal selenium catalyst for an almost $75 \%$ yield [36].

\section{Industrial Methods for NA Production}

The industrial production of NA is based on the oxidation reaction of 5-ethyl-2methylpyridine or 3-methylpyridine. Figure 2 shows the methods for producing these raw materials [1]. When producing 5-ethyl-2-methylpyridine, an intermediate results from the trimerization of acetaldehyde to para-aldehyde in an acidic environment and is then reacted with $\mathrm{NH}_{3}$. 3-Methylpyridine is obtained from acrolein, which is reacted with $\mathrm{NH}_{3}$ in the gas phase; the main product is pyridine, while 3-picoline is produced as a by-product with $30-50 \%$ efficiency depending on the catalytic system [40]. The other method of obtaining 3-picoline is the catalytic hydrogenation of 2-methylglutaronitrile with a 50\% yield [40]. The industrial process of obtaining 5-ethyl-2-methylpyridine is more selective and efficient compared to 3-methylpyridine, making 5-ethyl-2-methylpyridine an attractive substrate even though the atom economy (25\%) for NA production is much lower using this raw material $[40,41]$.<smiles>CC=C[C@@H](C)C1OC(C)OC(C)O1</smiles>

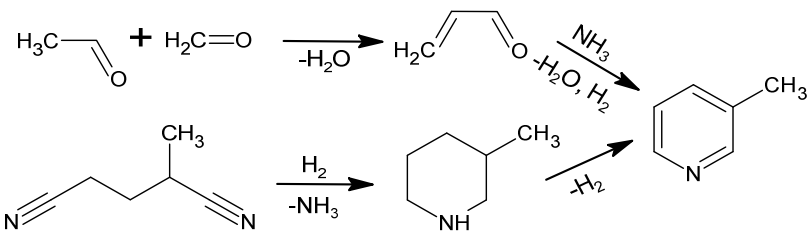

Figure 2. Industrial methods to produce 5-ethyl-2-methylpyridine or 3-methylpyridine.

The Swiss Lonza group has been producing NA since 1956 [42]. One of the first technologies used by Lonza was the catalytic, liquid-phase oxidation of 5-ethyl-2-methylpyridine with $\mathrm{HNO}_{3}$ (Figure 3). The oxidation process was carried out at $190-270{ }^{\circ} \mathrm{C}$ at $2-8 \mathrm{MPa}[1,43]$ 
to produce an unstable intermediate, 2,5-pyridinedicarboxylic acid (isocinchomeronic acid). The intermediate was decarboxylated at $220{ }^{\circ} \mathrm{C}$ to form NA, the crude product of which was isolated by crystallization. The total reaction time was approximately $45 \mathrm{~min}$, and the first processes ran with $80 \%$ conversion and $70 \%$ efficiency [43].

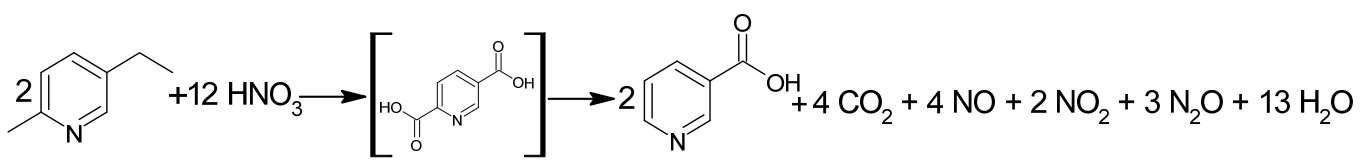

Figure 3. Oxidation reaction of 5-ethyl-2-methylpyridine using $\mathrm{HNO}_{3}$.

The Lonza group refined their process by increasing the stoichiometric excess of $\mathrm{HNO}_{3}$ in the range of $25-600 \%$. With such a large excess of acid and at temperatures below $20{ }^{\circ} \mathrm{C}$, NA crystallized in the form of a colorless salt with $\mathrm{HNO}_{3}$. Once separated, the reaction mixture was dissolved in water, and the $\mathrm{pH}$ value was adjusted with the appropriate amount of base to release the crystalline NA.

This process forms $\mathrm{NO}$ that oxidizes with the air to $\mathrm{NO}_{2}$, which is then absorbed into water to allow $\mathrm{HNO}_{3}$ to return to the process [43]. Due to the highly corrosive environment, the process uses a tubular reactor made of titanium or, if operated at the upper pressure limits, a steel reactor with a titanium coating. In this way, the continuous process of NA production achieves $96 \%$ conversion and a $91 \%$ yield [43].

Industrially, NA is also produced by gas-phase ammoxidation of 3-picoline to 3cyanopyridine, followed by hydrolysis to nicotinamide or NA (Figure 4). This process uses a fluidized bed reactor and a heterogeneous catalyst and has been of great interest for 30 years in Europe, Asia, and India [41,44].

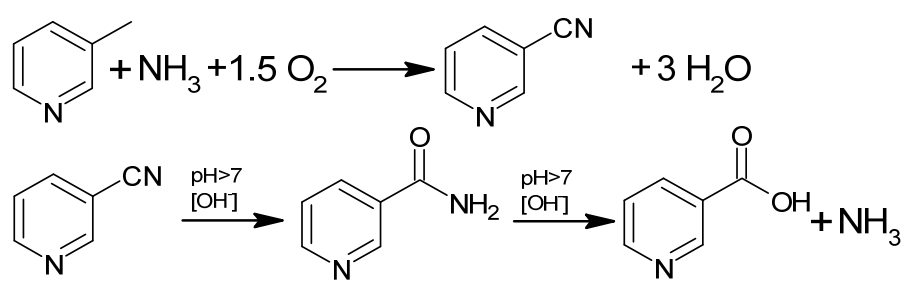

Figure 4. Oxidative ammonolysis of 3-picoline followed by hydrolysis to NA.

In a multi-tube bed reactor, 3-methylpyridine, air, and $\mathrm{NH}_{3}$ react at temperatures in the range of $280-500{ }^{\circ} \mathrm{C}$ under a pressure of $0.5 \mathrm{MPa}$. Typically, the input mixture is 1-20 moles of $\mathrm{NH}_{3}$ and 2-20 moles of oxygen per 1 mole of 3-picoline, but the process parameters depend on the type of catalytic system. Catalytic systems most often contain vanadium(V) oxide, its mixtures, or other oxides containing metals such as titanium(IV), zirconium(VI), and molybdenum(VI) for the process carried out at $340^{\circ} \mathrm{C}$ [40]. For example, ammoxidation of 3-methylpyridine in the presence of a molybdenum catalyst supported on silica gel produced 3-cyanopyridine with a 95\% yield, 99\% conversion, and a residence time of only $2.5 \mathrm{~s}$ at $380{ }^{\circ} \mathrm{C}$ [45]. Using $\mathrm{V}_{2} \mathrm{O}_{5}$, Lonza obtained an $83.5 \%$ yield of cyanopyridine with a conversion rate of $89.3 \%[40,46]$. The $\mathrm{MoO}_{3}-\mathrm{V}_{2} \mathrm{O}_{5}$ system used by Yuki Gousei, as well as the $\mathrm{V}_{2} \mathrm{O}_{5}-\mathrm{P}_{2} \mathrm{O}_{5}-\mathrm{SiO}_{2}$ system used in the Koei Chemical process, led to an $82 \%$ yield of cyanopyridine with a conversion rate of $96 \%[40,47,48]$. The $\mathrm{V}_{2} \mathrm{O}_{5}-\mathrm{Sb}_{2} \mathrm{O}_{5}-\mathrm{TiO}_{2}-$ $\mathrm{SiO}_{2}-\mathrm{SiC}$ system used by Nippon Shokubai obtained an $85 \%$ yield of cyanopyridine [40]. Using the $\mathrm{Sb}_{2} \mathrm{O}_{5}-\mathrm{V}_{2} \mathrm{O}_{5}-\mathrm{TiO}_{2}-$ montmorillonite- $\mathrm{SiO}_{2}$ system, Degussa obtained cyanopyridine with a yield of $90 \%$ and a raw material conversion of $94 \%$ [40,49]. The system used by Takeda Chemical is the best; $\mathrm{V}_{2} \mathrm{O}_{5}-\mathrm{Sb}_{2} \mathrm{O}_{5}-\mathrm{Cr}_{2} \mathrm{O}_{3}-\mathrm{TiO}_{2}$ produces an almost $99 \%$ yield of cyanopyridine at $100 \%$ conversion $[40,50]$.

The future lies in enzymatic methods that can efficiently and selectively produce NA directly from 3-cyanopyridine [51]. 
Table 1 presents selected advantages and disadvantages of the oxidation of 5-ethyl-2methylpyridine with $\mathrm{HNO}_{3}$.

Table 1. Advantages and disadvantages of the process of obtaining nicotinic acid from 5-ethyl-2methylpyridine.

\begin{tabular}{ll}
\hline Advantages & Disadvantages \\
\hline commercial raw material & $\mathrm{HNO}_{3}$ as an oxidant, used in large excesses \\
high efficiency $91 \%$ & $\mathrm{NOx}$ by-products \\
high conversion $96 \%$ & highly corrosive reaction environment \\
well-known process & low atom economy (ca. $25 \%)$ \\
& oxidation time $>1 \mathrm{~h}$ \\
& high pressure $2-8 \mathrm{MPa}$ \\
& high temperature $190-270{ }^{\circ} \mathrm{C}$ \\
\hline
\end{tabular}

\section{Oxidation of 3-Methylpyridine in the Liquid Phase}

The literature describes the oxidation of 3-methylpyridine in the liquid phase (Figure 5) with the use of environmentally friendly oxidizing agents, such as oxygen, $\mathrm{H}_{2} \mathrm{O}_{2}$, organic hydroperoxides, and peroxy acids, as well as non-ecological ones, such as $\mathrm{HNO}_{3}$.<smiles>Cc1cccnc1</smiles>

Figure 5. Oxidation of 3-picoline in the liquid phase.

The first attempts to oxidize 3-methylpyridine with concentrated $\mathrm{HNO}_{3}$ in $\mathrm{H}_{2} \mathrm{SO}_{4}$ medium were made by Reilly Tar \& Chemical Corporation in 1945 [52]. Almost 30 years later, Lonza patented the oxidation of 3-methylpyridine to $\mathrm{NA}$ with $\mathrm{HNO}_{3}$ but without $\mathrm{H}_{2} \mathrm{SO}_{4}$ [53]. The reaction was carried out at $260{ }^{\circ} \mathrm{C}$ under a pressure of 5-6 $\mathrm{MPa}$ to obtain NA with an $89 \%$ yield and a raw material conversion rate of $69 \%[33,43,52]$. In addition to the low technological parameters, the process is associated with the same disadvantages as discussed for the oxidation of 5-ethyl-2-methylpyridine. The process produces approximately $180 \mathrm{~kg}$ of $\mathrm{N}_{2} \mathrm{O}$ per ton of $\mathrm{NA}$, and thus the method does not appear to be the best alternative, despite the lower greenhouse gas emissions and the higher atom economy of approximately $36 \%$.

In the twentieth and twenty-first centuries, production plants in Japan, including Daicel, Mitsubishi, and Nissan, studied the oxidation of 3-picoline in the liquid phase with oxygen or air using the Amoco catalytic system, $\mathrm{Co}(\mathrm{II})$ and $\mathrm{Mn}$ (II) compounds with the addition of bromide salt, and most commonly with $\mathrm{AcOH}$ as the solvent [41].

Nissan proposed the oxidation of 3-methylpyridine with air in a catalytic system of $\mathrm{Co}(\mathrm{OAc})_{2}, \mathrm{Mn}(\mathrm{OAc})_{2}, \mathrm{NaBr}$, and $\mathrm{HCl}$ gas in $\mathrm{AcOH}$ solvent [53]. The process was carried out at $80{ }^{\circ} \mathrm{C}$ and under a pressure of $10 \mathrm{MPa}$ for $2 \mathrm{~h}$ to obtain $98 \%$ conversion and a $97 \%$ yield. The presence of the chloride derivative is key for the method and affects the yield of the process; when carried out without the presence of chlorides, the process achieves a conversion of only $60-80 \%$ depending on the conditions used [54].

Mitsubishi developed a system in which 3-methylpyridine is oxidized against $0.15-0.5 \%$ $\mathrm{Co}(\mathrm{OAc})_{2}$ and $\mathrm{Mn}(\mathrm{OAc})_{2}$ and $0.1-1.5 \%$ bromides in $\mathrm{AcOH}$. The reaction was carried out at $210{ }^{\circ} \mathrm{C}$ and under $2.5 \mathrm{MPa}$ pressure for $3 \mathrm{~h}$ to result in $93.7 \%$ conversion with $99 \%$ selectivity [55]. The company focused on developing a method where the final products could be purified from catalysts used in the reaction. However, bromides remained a problem at more than 600 ppm in the purified NA, and thus the obtained NA was passed together with water and $\mathrm{H}_{2}$ through a reactor with a $\mathrm{Pd}$ catalyst deposited on active carbon. The process was carried out at $130{ }^{\circ} \mathrm{C}, 0.6 \mathrm{MPa}$, for $2 \mathrm{~h}$, to reduce the presence of bromides in the purified NA by more than $90 \%$ [56]. In another rendition, Daicel investigated the 
$\mathrm{Co}(\mathrm{OAc})_{2}$ and $\mathrm{Mn}(\mathrm{OAc})_{2}$ system with the addition of $N$-hydroxyphthalimide (NHPI) to obtain very pure NA at $150{ }^{\circ} \mathrm{C}$ and $2 \mathrm{MPa}$; unfortunately, the selectivity of the process was only $80 \%$ [56].

A variant of 3-methylpyridine oxidation that uses oxygen or air without additional metal catalysts is using a mixture of protic and aprotic solvents [57]. The best results were an $85-100 \%$ yield for NA with the 1,3-dimethyl-3,4,5,6-tetrahydro-2(1H)-pyrimidone: tetrahydrofuran (DMPU:THF) system, with oxygen serving as the oxidizing agent, where the reaction proceeded at $60-80{ }^{\circ} \mathrm{C}$ and under $1 \mathrm{MPa}$ pressure for 5-10 min. A system with dimethoxyethane (DME) and THF obtained NA with only a $10 \%$ yield under analogous conditions. A solvent system with potassium tert-amylate ( $\mathrm{t}$-OAmK), hexamethylphosphoramide (HMPA) in DMPU:THF with air allowed for a maximum yield of $78 \%$ NA at 60-80 ${ }^{\circ} \mathrm{C}$ and $1 \mathrm{MPa}$ for 5-10 $\min$ [57].

Another way to obtain NA from 3-methylpyridine is catalytic oxidation with oxygen in water under supercritical conditions. The process was carried out for $1.5 \mathrm{~h}$ at $380{ }^{\circ} \mathrm{C}$ and $22 \mathrm{MPa}$ pressure with the use of supercritical water in the presence of $\mathrm{MbBr}_{2}$ as a catalyst, thereby producing NA with 30\% conversion and 95\% selectivity [58]. The reaction carried out with the same catalyst at $260{ }^{\circ} \mathrm{C}$ and $22 \mathrm{MPa}$ allowed, in turn, the conversion of 3 -picoline to NA with $83 \%$ conversion and $66 \%$ selectivity [59].

The latest research on NA production focuses on using UV-A radiation in the photocatalytic oxidation process with $\mathrm{TiO}_{2}$ at various $\mathrm{pH}$ values in an aqueous suspension. The commercially available Degussa-P25 catalyst has been used, as have the HPRT, HP60, and $\mathrm{HP} 100$ catalysts, which were prepared at room temperature, $60^{\circ} \mathrm{C}$, and $100{ }^{\circ} \mathrm{C}$, respectively, with and without the presence of mineral acids. Oxidation at $\mathrm{pH} 7$ for $3 \mathrm{~h}$ with the DegussaP25 catalyst resulted in $88 \%$ feed conversion and 4\% selectivity to NA. The HP100 catalyst with $3 \mathrm{M} \mathrm{HCl}$ catalyst produced NA with a maximum degree of conversion of $66 \%$ and with $5 \%$ selectivity. The HPRT catalyst proved to be much better with a conversion of $40 \%$ and a selectivity greater than $12 \%$. Optimization of the $\mathrm{pH}$ to 2 for the Degussa-P25 catalyst obtained a maximum conversion of $14 \%$ and selectivity of $15 \%$; in turn, the pH of 12.7 made it possible to obtain $18 \%$ selectivity, with the conversion of raw material amounting to $89 \%$. At the same $\mathrm{pH}$ value of 12.7 , the $\mathrm{HP} 100-3 \mathrm{M} \mathrm{HCl}$ catalyst produced decent results of $60 \%$ conversion and $14 \%$ selectivity [60].

There are also reports on attempts to oxidize 3-picoline in the liquid phase, in the presence of a $\mathrm{Ag}-\mathrm{Mn}_{3} \mathrm{O}_{4}$ catalytic system deposited on nanorods with a diameter of $20 \mathrm{~nm}$ [61]. Oxidation was carried out using $\mathrm{H}_{2} \mathrm{O}_{2}$ with $\mathrm{MeCN}$ as a solvent, at $70{ }^{\circ} \mathrm{C}$, and under atmospheric pressure for $15 \mathrm{~h}$ to obtain approximately $55 \%$ conversion, with selectivity to NA reaching 97\%. Another example of liquid-phase oxidation is the oxidation of 3picoline using tert-butyl hydroperoxide (TBHP) and oxygen as the oxidizing agents [62]. The process was performed at $80{ }^{\circ} \mathrm{C}$ for $48 \mathrm{~h}$ in a water solvent with reusable binaphthylstabilized Pt nanoparticles (Pt-BNP), which served as a catalyst to obtain 58\% efficiency in producing NA.

Liquid-phase oxidation has also been investigated with peracetic acid using acetylperoxyborate (APB) as the oxidizing agent, along with the presence of Ir-Bi cluster complexes on a silica support with DME solvent [63]. The processes carried out at $65^{\circ} \mathrm{C}$ for $45 \mathrm{~min}$ with $\mathrm{Ir}_{3} \mathrm{Bi}$ and $\mathrm{Ir}_{5} \mathrm{Bi}_{3}$ catalysts produced NA with a selectivity of $91 \%$ and $84 \%$, respectively. Ir and Bi catalysts produced NA with $67 \%$ and $43 \%$ selectivity, respectively.

Table 2 presents selected advantages and disadvantages of the oxidation of 3-methyl pyridine with air in relation to the $\mathrm{Co} / \mathrm{Mn} / \mathrm{Br}$ system. 
Table 2. Advantages and disadvantages of the process of obtaining nicotinic acid by 3-methylpyridine oxidation with air in a liquid phase catalyzed by $\mathrm{Co} / \mathrm{Mn} / \mathrm{Br}$.

\begin{tabular}{ll}
\hline Advantages & Disadvantages \\
\hline commercial raw material & the technology needs further research \\
high efficiency $97 \%$ & highly corrosive reaction environment \\
high conversion $98 \%$ & oxidation time $>3 \mathrm{~h}$ \\
oxygen as an oxidant & high pressure $2-10 \mathrm{MPa}$ \\
harmless by-products & use of a polar solvent \\
high atom economy $(87 \%)$ & \\
temperature $80-210^{\circ} \mathrm{C}$ & \\
\hline
\end{tabular}

\section{Oxidation of 3-Methylpyridine in the Gas Phase}

Gas-phase oxidation of 3-methylpyridine using heterogeneous catalysts has been known for more than 60 years, but only in the last 30 years have attempts been made to develop a commercial process. According to the principles of "green chemistry", the process is solvent free and carried out in the presence of heterogeneous catalysts. Such late interest results from many difficulties, including easy decarboxylation and desublimation at the process temperature, the slower course of the reaction, and the formation of several byproducts because of complete oxidation as compared to the liquid-phase process $[33,41,51]$. The most recent review on producing NA was published in 2009 [51], but since then, there have been literature reports concerning new catalyst systems and solutions for producing NA from 3-methylpyridine in the gas phase.

Researchers at the Boreskov Institute and Lonza have developed pilot processes for NA production using $\mathrm{V}_{2} \mathrm{O}_{5}$ and $\mathrm{TiO}_{2}$ oxide catalysts and proposed isolating $\mathrm{NA}$ by the desublimation method, a Lonza technology based on spray drying [41]. Jubilant Life Sciences used $\mathrm{TiO}_{2}, \mathrm{~V}_{2} \mathrm{O}_{5}$, and $\mathrm{Sb}_{2} \mathrm{O}_{3}$ catalysts and decided to isolate NA by absorption and crystallization [64]. Additionally, researchers at the Boreskov Institute carried out a process by passing 3-methylpyridine, oxygen, and water vapor through a reactor with a catalyst deposited on a carrier at a temperature of $250-290{ }^{\circ} \mathrm{C}$. The influence of the weight ratio of vanadium oxide to titanium oxide was also investigated, and the most advantageous ratio was $20 \mathrm{wt} \% \mathrm{~V}_{2} \mathrm{O}_{5}$ to $80 \mathrm{wt} \% \mathrm{TiO}_{2}$, which produced NA with an $85 \%$ yield in $1.5 \mathrm{~s}$, with a conversion rate of $91 \%$. In addition to NA, the reaction produces $\mathrm{CO}_{2}$ and nicotinic aldehyde (PA) [65]. The reactor stream is then directed to a tubular crystallizer, where NA is separated by desublimation at $160-200{ }^{\circ} \mathrm{C}$ to generate a final product with $99.5 \%$ NA [65]. Tests on a pilot scale used the $\mathrm{V}_{2} \mathrm{O}_{5}-\mathrm{TiO}_{2}$ catalyst at $260-290{ }^{\circ} \mathrm{C}$ with a reaction time of less than $7 \mathrm{~s}$ and converted a maximum of $97 \%$ of the raw material, with a maximum yield of NA of $75 \%$ [66].

Lonza investigated catalytic systems with $\mathrm{V}_{2} \mathrm{O}_{5}$ deposited on a silica support or titanium oxide [33]. The raw material was almost quantitatively converted into NA, and insignificant amounts of PA were produced. Instead, the focus was on product isolation problems. After passing through the NA vapor reactor, hot air and water vapor partially condensed during absorption and in the distillation column. The solubility of NA in water is low even at $100^{\circ} \mathrm{C}(9.8 \mathrm{~g} / 100 \mathrm{~mL})$ [1], meaning a considerable amount of water is needed to dissolve the obtained NA product, water which then must be removed in the later stages of the processing at much energy expense. An additional problem is the presence of ammonium ions, which reduce the amount of NA that can be crystallized due to the good solubility of ammonium nicotinate. Ammonium nicotinate decomposes above $160{ }^{\circ} \mathrm{C}$, a fact that prompted the Lonza group to absorb the NA product on an absorption column and convert most of the NA product to an ammonium salt by adding $\mathrm{NH}_{3}$, and then spray drying with a drying gas (air, nitrogen, argon) at $160-250{ }^{\circ} \mathrm{C}$ [67]. The final NA product does not require additional purification and does not tend to cake.

Alternatively, Jubilant Life Sciences decided to absorb post-reaction gases in water, filter, crystallize, and dry. The process of passing 3-methylpyridine, oxygen, and water vapor through a reactor with a catalyst, consisting of $\mathrm{TiO}_{2}, \mathrm{~V}_{2} \mathrm{O}_{5}$, and $\mathrm{Sb}_{2} \mathrm{O}_{3}$ deposited on 
a carrier, at a temperature of $250-290{ }^{\circ} \mathrm{C}$ obtained NA with almost $95 \%$ conversion and $91 \%$ selectivity [64].

A literature review of the catalysts for oxidation over the last 50 years shows progress in the design of catalytic systems that allow the reaction temperature to be decreased, as well as a marked increase in the degree of conversion of raw material and selectivity to the desired product [68]. The oldest catalytic systems were described in 1969 and consisted of $\mathrm{SnVO}_{4}$ and $\mathrm{TiVO}_{4}$ in the presence of water vapor to oxidize 3-methylpyridine with air, which produced PA and NA with a total selectivity of 75-77\%. For $\mathrm{SnVO}_{4}$, the highest NA yield was 35\%, and for $\mathrm{TiVO}_{4}$, it was 50\%. Lower NA yields were obtained with the $\mathrm{V}-\mathrm{Al}$ and V-Sn catalysts, whereas with the V-Ti catalysts developed in 1976, efficiency exceeded 50\% [69]. A breakthrough in 3-methylpyridine oxidation came with the use of V-Ti systems, resulting in an $85 \%$ yield followed by a surprising $97 \%$ yield with a selectivity of more than $99 \%$. Using promoters of molybdenum, tellurium, tin, cesium, and zirconium increased the activity of V-Ti catalysts but had little effect on selectivity. Catalysts with a lower $\mathrm{V}_{2} \mathrm{O}_{5}$ content (5-10\%) and with additional oxides of chromium, iron, and tungsten achieved 90\% efficiency. The three-component catalysts obtained NA with a yield of approximately $82 \%$ and selectivity in the range of $90-93 \%$, regardless of the amount of vanadium. Comparison of catalysts with different compositions led to the conclusion that the efficiency of V-Ti catalysts decreased with increasing vanadium content in the range of 5-25\% [68].

Degussa conducted research on the effect of the $\mathrm{SO}_{4}{ }^{2-}$ ion in the carrier. Catalysts containing $0.5 \% \mathrm{SO}_{4}{ }^{2-}$ exhibited efficiencies ranging from 84 to $97 \%$, and when the $\mathrm{SO}_{4}{ }^{2-}$ content increased to $1.5 \%$, NA yield and selectivity decreased. This was most likely due to the acid-base properties of the reaction mixture and the acidic and basic surface sites of the catalysts. Acid centers can strongly influence the direction of conversion of aldehydes to acids or complete oxidation products, while basic centers result in better selectivity to aldehydes. When the $\mathrm{SO}_{4}{ }^{2-}$ ion concentration increased, excessive oxidation of both NA and PA likely occurred [68].

Researchers at the Bekturov Institute of Chemical Sciences have studied the effect of $\mathrm{Al}_{2} \mathrm{O}_{3}, \mathrm{SnO}_{2}$, and $\mathrm{ZrO}_{2}$ additives to vanadium catalysts $[69,70]$. Tests at $300{ }^{\circ} \mathrm{C}$ for a $1: 1$ ratio of $\mathrm{V}_{2} \mathrm{O}_{5}: \mathrm{Al}_{2} \mathrm{O}_{3}$ obtained $\mathrm{NA}$ with $64 \%$ efficiency and $94 \%$ selectivity, while a 2:1 ratio obtained NA with only $47 \%$ efficiency but almost $96 \%$ selectivity [69]. The institute also carried out a pilot-scale study, which showed greater activity and more favorable results using the $\mathrm{V}_{2} \mathrm{O}_{5}-\mathrm{ZrO}_{2}-\mathrm{TiO}_{2}$ system as opposed to $\mathrm{V}_{2} \mathrm{O}_{5}-\mathrm{SnO}_{2}-\mathrm{TiO}_{2}$, and $\mathrm{NA}$ was obtained with 75-77\% efficiency and 90\% selectivity [70].

Among vanadium-based catalysts, $\mathrm{CrVO}_{4}$ has been found to be most effective, with an overall yield of PA and NA of approximately 50\%. The aluminum and phosphorus promoters strongly increase the overall yield to $69 \%$ and $83 \%$, respectively. For the CrVP catalyst, NA was obtained with an efficiency of 78\%, while selectivity reached $84 \%$ [68].

There are reports in the literature on the use of vanadyl pyrophosphate (VPP) as a catalyst for the oxidation of 3-picoline [71]. The process at $310{ }^{\circ} \mathrm{C}$ obtained NA with only $14 \%$ efficiency, but efficiency increased up to $36 \%$ with the addition of steam to the system. The presence of water also had a positive effect on the degree of conversion of the raw material, up to a maximum yield of $55 \%$ at $330{ }^{\circ} \mathrm{C}$, with optimization of the raw material composition and reaction parameters. Additionally, an interesting solution was to carry out the process in the gas phase using a microwave reactor [72]. The process used a catalyst system with $20 \% \mathrm{~V}_{2} \mathrm{O}_{5}$ and $80 \% \mathrm{TiO}_{2}$ that was heated with microwaves to achieve $95 \%$ selectivity to NA at a much lower temperature of $180{ }^{\circ} \mathrm{C}$. This method also lowered energy consumption.

Table 3 presents selected advantages and disadvantages of the gas-phase oxidation of 3-methylpyridine with air. 
Table 3. Advantages and disadvantages of obtaining nicotinic acid by 3-methylpyridine oxidation with air in the gas phase.

\begin{tabular}{ll}
\hline Advantages & Disadvantages \\
\hline $\begin{array}{l}\text { commercial raw material } \\
\text { high efficiency } 91 \%\end{array}$ & $\begin{array}{l}\text { the technology needs further research } \\
\text { slightly corrosive reaction environment } \\
\text { high conversion } 95 \%\end{array}$ \\
$\begin{array}{l}\text { high temperature }>250{ }^{\circ} \mathrm{C} \\
\text { the product impurities }\end{array}$ \\
$\begin{array}{l}\text { harmless by-products } \\
\text { high atom economy }(87 \%)\end{array}$ \\
$\begin{array}{l}\text { oxidation time }<10 \mathrm{~min} \\
\text { low pressure } 0.1 \mathrm{MPa}\end{array}$ \\
\hline
\end{tabular}

\section{Oxidative Ammonolysis of 3-Methylpyridine}

Oxidative ammonolysis of 3-methylpyridine in the gas phase to 3-cyanopyridine, followed by hydrolysis to nicotinic acid amide or NA, is an industrial-scale process of great interest for 30 years [41].

One of the first published methods was a Reilly Tar \& Chemical Corporation patent in $1960[40,41]$. The method consisted of passing 3-methylpyridine, air, and $\mathrm{NH}_{3}$ through a reactor with a catalyst bed at a temperature of $280-500{ }^{\circ} \mathrm{C}$ and a pressure up to $0.5 \mathrm{MPa}$ [40]. The catalyst used in the method was most often $\mathrm{V}_{2} \mathrm{O}_{5}$, its mixtures, or other metal oxides [40]. The progress described in the literature optimized this catalytic system [41]. An oxide system consisting of $\mathrm{V}_{2} \mathrm{O}_{5}, \mathrm{MoO}_{3}, \mathrm{ZrO}_{2}$, and $\mathrm{TiO}_{2}$ achieved $95 \%$ conversion at $340{ }^{\circ} \mathrm{C}$ [1]. Further, a reaction using a molybdenum catalyst on silica gel, carried out at $380{ }^{\circ} \mathrm{C}$ with a residence time of $2.5 \mathrm{~s}$, obtained 3-cyanopyridine in a $95 \%$ yield with a conversion of $99 \%$ [46]. Takeda Chemical used a catalyst consisting of $\mathrm{V}_{2} \mathrm{O}_{5}, \mathrm{Sb}_{2} \mathrm{O}_{5}, \mathrm{Cr}_{2} \mathrm{O}_{3}$, and $\mathrm{TiO}_{2}$ to achieve a yield of $98.6 \%$ and $100 \%$ conversion [40].

$\mathrm{V}-\mathrm{W}-\mathrm{O}$ systems use a mixture of $\left(\mathrm{NH}_{4}\right)_{6}\left[\mathrm{H}_{2} \mathrm{~W}_{12} \mathrm{O}_{40}\right] \cdot \mathrm{nH}_{2} \mathrm{O}, \mathrm{VOSO}_{4} \cdot \mathrm{nH}_{2} \mathrm{O}$, and oxalic acid and have allowed for $99.5 \%$ selectivity to 3-cyanopyridine [73]. The $\mathrm{V}-\mathrm{W}-\mathrm{O}$ system made it possible to obtain higher technological indices than the $\mathrm{VOx}-\mathrm{WO}_{3}$ systems described in the literature and other vanadium-based systems.

The process of obtaining 3-cyanopyridine is perfectly adapted for industrial production, but the main purpose of the process is to obtain nicotinic acid amide. Further hydrolysis of the amide to NA is regarded as a side reaction that decreases selectivity. Nevertheless, methods have been described to successfully obtain NA.

NA has been obtained by alkaline hydrolysis with the use of catalytic amounts of $10 \%$ $\mathrm{NaOH}$ or $\mathrm{KOH}$ at $190^{\circ} \mathrm{C}$ under a pressure of $1.5-2 \mathrm{MPa}[1,74,75]$. The obtained products were passed through a column with an ion exchange resin, which separated NA from its amide and resulted in a high purity of the products [76]. Another example described in the literature was catalytic hydrolysis using a $5 \% \mathrm{NaOH}$ and $\mathrm{MnO}_{2}$ solution carried out in $\mathrm{EtOH} / \mathrm{H}_{2} \mathrm{O}$ at $85-100{ }^{\circ} \mathrm{C}$. After the process was complete, $\mathrm{MnO}_{2}$ was removed, and the solvent was evaporated [77].

The use of various types of bacteria has been studied for 20 years, including Rhodococcus rhodochrous that had high benzonitrilase activity and ensured $100 \%$ conversion of 3-cyanopyridine to NA [78]. Studies have also included the use of Nocardia rhodochrous bacteria in column bioreactors and Bacillus pallidus bacteria that produced a thermostable nitrilase to catalyze the hydrolysis of 3-cyanopyridine to NA without forming detectable nicotinamide $[79,80]$. An additional biotransformation, fungal nitrilases may convert 3cyanopyridine to NA. The most promising biotransformation for NA production, however, seems to be plant amidases that can be used in stirred membrane bioreactors, a potentially continuous bioprocess that can be used in industry [81]. Still, the greatest challenge is the duration of enzyme activity that is used for the biotransformation.

The use of bipolar membrane electrodialysis (BMED) is a green process that can produce NA by oxidative ammonolysis [82]. The hydrolysis process yields the sodium salt 
of NA that can be converted to NA. Laboratory-scale tests have shown that for the highest achieved efficiency of $95.9 \%$, the process consumes $4.14 \mathrm{kWh}$ of energy per $1 \mathrm{~kg}$ NA.

In the literature, there are attempts to obtain NA directly in the oxidative ammonolysis process carried out in the liquid phase, using a catalyst of nanoclusters of $\operatorname{Re}_{2} S b, \operatorname{Re}_{2} \mathrm{Sb}_{2}$, or $\mathrm{Re}_{2} \mathrm{Bi}_{2}$ deposited on a silica support [83]. The process used a toluene solvent, was carried out at $120-150{ }^{\circ} \mathrm{C}$ for $6 \mathrm{~h}$, and achieved conversion rates of up to $70 \%$ with a maximum selectivity to NA of $6.9 \%$ and a selectivity to 3-cyanopyridine of approximately $80 \%$.

Table 4 presents selected advantages and disadvantages of the oxidative ammonolysis process of 3-methylpyridine.

Table 4. Advantages and disadvantages of the process of obtaining nicotinic acid by the 3methylpyridine oxidative ammonolysis process.

\begin{tabular}{ll}
\hline Advantages & Disadvantages \\
\hline commercial raw material & low efficiency $85 \%$ \\
high conversion $96 \%$ & slightly corrosive reaction environment \\
well-known process & high temperature $>250{ }^{\circ} \mathrm{C}$ \\
$\mathrm{HNO}_{3}+\mathrm{O}_{2}$ as an oxidant & process complexity \\
harmless by-products & $\begin{array}{l}\text { low yield of 3-cyanopyridine hydrolysis to } \\
\text { nicotinic acid }\end{array}$ \\
oxidation time $<10 \mathrm{~min}$ & low atom economy (66\% for the preparation of \\
low pressure $0.1-1 \mathrm{MPa}$ & 3-cyanopyridine) \\
\hline
\end{tabular}

\section{Other Methods of Obtaining NA}

The oxidative ammonolysis of 5-ethyl-2-methylpyridine has been studied for 30 years. Problems in this process remain, and optimization is needed to limit the formation of 2,5-dicyanopyridine and increase the yield of 3-cyanopyridine. The developed methods introduce the raw material into a reactor together with oxygen, $\mathrm{NH}_{3}$, and steam, use catalysts $\mathrm{V}_{2} \mathrm{O}_{5}, \mathrm{MoO}_{3}$, and $\mathrm{ZrO}_{2}$, and perform the reaction at a temperature of $350-400{ }^{\circ} \mathrm{C}$. The use of the $\mathrm{VTi}_{8} \mathrm{O}_{\mathrm{x}}$ catalyst at $350{ }^{\circ} \mathrm{C}$ allowed for a $75 \%$ yield of 3-cyanopyridine $[84,85]$, which would then be hydrolyzed in the next step of the process. The low yield of 3-cyanopyridine, as well as problems with selective hydrolysis to NA, makes this process unjustified.

Electrochemical oxidation is another method that has been studied for several decades. The initial results of the experiments led to the formation of tar that corroded the electrodes. A system with a $\mathrm{Pb}$ - $\mathrm{Ag}$ anode with variable $\mathrm{Ag}$ content and a $\mathrm{Pt}$ cathode was used to oxidize 3-methylpyridine but did not obtain satisfactory results. Oxidation of 5ethyl-2-methylpyridine gave 2,5-pyridinedicarboxylic acid and 6-methylnicotinic acid [86]. Oxidation of 3-methylpyridine using a cell with a Sn anode and Pt cathode increased the NA concentration to saturation of the electrolyte with the product [87]. Laboratory tests using $\mathrm{Pb}$ cells to oxidize 3-methylpyridine also achieved good selectivity and current efficiency. This process has been estimated to consume $11 \mathrm{MWh}$ of electricity to produce 1 ton of NA [41]; this power consumption makes the method uneconomical at current energy prices.

\section{Conclusions}

The industrial process of NA production by oxidation of 5-ethyl-2-methylpyridine with nitric acid is not environmentally friendly due to gaseous by-products $\left(\mathrm{NO}_{\mathrm{x}}\right)$ and low atom economies. Manufacturers must meet the growing demand for the NA product and develop a method that is selective, economical, and in line with the principles of green chemistry. Hence, in recent years, many studies have been carried out, on both a laboratory scale and a pilot scale.

The process of oxidizing 3-methylpyridine in the liquid phase using green oxidizing agents has achieved relatively good selectivity to the desired NA product; the undoubted advantage is the low amount of waste and high atom economy $(87 \%)$. However, these 
processes use solvents that contribute to corrosiveness and require processes to purify and separate the metallic catalysts in the solution, processes which are associated with high energy expenditure and water consumption.

The oxidative ammonolysis of 3-methylpyridine is a green process as the only byproduct of the reaction is water. Unfortunately, the great disadvantage of this method is that it is intended to produce nicotinamide and has problems associated with implementations for the selective production of NA from 3-cyanopyridine.

Presently, the gas-phase oxidation of 3-picoline seems to be one of the best methods to produce NA with high selectivity as well as a high atom economy of $87 \%$. This process offers very attractive advantages, such as the use of air as the oxidant, energy recovery from the exothermic reaction, and low wastage. Nevertheless, some authors mentioned that the obtained product may contain some impurities that limit its applications.

Based on the literature review, we believe that the oxidation of 3-methylpyridine to NA in the liquid phase can also be implemented in the industry. The process appears to be relatively simple and limited to a few unit operations. The use of air as an oxidizing agent and the high yields and conversions are the advantages of this method. However, the high corrosivity of the $\mathrm{Co} / \mathrm{Mn} / \mathrm{Br}$ catalytic system and resulting need to use an appropriate construction material or corrosion inhibitors should be taken into account [88].

Author Contributions: Conceptualization, D.L. and B.O.; writing-original draft preparation, D.L. and K.N.; supervision, D.L. and B.O. All authors have read and agreed to the published version of the manuscript.

Funding: This research was funded by Rector of the Silesian University of Technology grant No. 04/050/RGP20/0114 and by the Silesian University of Technology grants No. 04/050/BKM21/0135 and 04/050/BK_21/0116.

Institutional Review Board Statement: Not applicable.

Informed Consent Statement: Not applicable.

Data Availability Statement: Data is contained within the article.

Conflicts of Interest: The authors declare no conflict of interest.

\section{References}

1. Blum, R. Vitamins, 11. Niacin (Nicotinic Acid, Nicotinamide). In Ullmann's Encyclopedia of Industrial Chemistry, 6th ed.; Wiley-VCH: Weinheim, Germany, 2015; pp. 1-9.

2. Available online: https://www.fiormarkets.com/report/global-niacin-vitamin-b3-market-growth-2019-2024-368719.html (accessed on 26 March 2021).

3. Available online: https:// dailymed.nlm.nih.gov/dailymed/drugInfo.cfm?setid=ce739d68-d89c-437c-90fb-3c0c45140f22 (accessed on 26 March 2021).

4. Available online: https://www.heartvein.com/supplements-for-varicose-veins/ (accessed on 26 March 2021).

5. Ida, C.; Ogata, S.; Okumara, K.; Taguchi, H. Induction of Differentiation in K562 Cell Line by Nicotinic Acid-Related Compounds. Biosci. Biotechnol. Biochem. 2009, 73, 79-84. [CrossRef] [PubMed]

6. Zhang, T.; Shi, W. Nicotinic Acid Injection for Treating Heart Diseases and Preparation Method Thereof. CN Patent 106377609, 8 February 2017.

7. Mitchell, O.W. Niacin and Berberine Compositions and Methods of Use Thereof. U.S. Patent 2019358211, 28 November 2019.

8. Bagchi, D.; Preuss, H.G.; Kothari, S. Method and Composition for Preventing or Reducing the Symptoms of Insulin Resistance Syndrome. U.S. Patent 7153877, 26 December 2008.

9. Ping, C.; Minqing, T.; Duo, Y.; Guangliang, C.; Haipeng, L.; Xiping, X. Drug Combination Containing Nicotinic Acid, HMG-CoA Reductase Inhibitor and Alpha-Glucosidase Inhibitor. CN Patent 101590051, 2 December 2009.

10. Tuorkey, M.J.F.-A.; Abdul-Aziz, K.K. A pioneer study on the anti-ulcer activities of copper nicotinate complex [CuCl (HNA) $\left.)_{2}\right]$ in experimental gastric ulcer induced by aspirin-pyloris ligation model (Shay model). Biomed. Pharmacoter. 2009, 63, 194-201. [CrossRef] [PubMed]

11. Elfarrah, K.; Saragovi, U.; Bassili, J. Combination of Antioxidant Substances for the Treatment of Alzheimer's Disease. CA Patent 2401452, 4 September 2003.

12. Rand, R. Medicinal Composition for Treating Symptoms Related to Parkinson's Disease. U.S. Patent 2016331759, 17 November 2016.

13. Carter, J. Method of Treating Neoplastic Disease in Human or Animal Patient. U.S. Patent 7939109, 10 May 2011. 
14. Medicine for Treating Breast Cancer and Its Preparation Method and Application. CN Patent 106852921, 16 June 2017.

15. Eleftheriadis, G.; Monou, P.K.; Andriotis, E.; Mitsouli, E.; Moutafidou, N.; Markopoulou, C.; Bouropoulos, N.; Fatouros, D. Development and Characterization of Inkjet Printed Edible Films for Buccal Delivery of B-Complex Vitamins. Pharmaceuticals 2020, 13, 203. [CrossRef]

16. Freitas, C.S.; Roveda, A.C.; Truzzi, D.R.; Garcia, A.C.; Cunha, T.M.; Cunha, F.Q.; Franco, D.W. Anti-inflammatory and antinociceptive activity of ruthenium complexes with isonicotinic and nicotinic acids (niacin) as ligands. J. Med. Chem. 2015, 58, 4439-4448. [CrossRef]

17. Bernstein, J.E. Method and Compositions for Treatment of Acne Vulgaris and Acne Rosacea. U.S. Patent 2005169948, 4 August 2005.

18. Hippe, T.; Schroeder, T. Haarreinigungsmittel Mit Strukturantien. DE Patent 102007062520, 25 June 2009.

19. Zhang, Y. Skincare Rich-Hydrogen Water Composition and Production Process and Application Thereof to Cosmetics. CN Patent 108143659, 12 June 2018.

20. Minghu, W. Sulfate Zinc-Plating Brightener. CN Patent 107557822, 9 January 2018.

21. Wang, Z. Electroplating Solution for Non-Cyanide Silver Electroplating. CN Patent 111101169, 5 May 2020.

22. Liu, X.; Pan, X.; Lu, M.; Sun, Y.; Wang, Z.; Zheng, Y. Nicotinic acid derivatives as corrosion inhibitors for mild steel in hydrochloric acid solutions: An experimental and computational chemistry study. J. Adhes. Sci. Technol. 2020, 35, 63-80. [CrossRef]

23. Zhu, J.; Yan, B.; Yan, X.; Jiang, P.; Wang, H. Chemical Polishing Method of Stainless Steel by High-Temperature Oxidation. CN Patent 103046053, 1 April 2015.

24. $\mathrm{Hu}, \mathrm{X}$. Electrolyte for Recycling Silver from Smelting Slag. CN Patent 103060845, 24 April 2013.

25. Jinpei, L.; Zhanjiang, Z. Application of Niacin Compound Serving as Toner in Direct Thermographic Material. CN Patent 101750870, 23 June 2012.

26. Martinez, C.; Delrieu, M.; Delpech, L.; Clerhues, T. Composition for Eliciting a Plant's Natural Defenses, Useful for Controlling Infections by Fungi, Bacteria or Viruses and Attack by Predators, Contains e.g. Plant Sapogenins. FR Patent 2871997, 30 December 2005.

27. Davarpanah, J.; Ghahremani, M.; Najafi, O. Synthesis of 1,4-dihydropyridine and polyhydroquinolinederivatives via Hantzsch reaction using nicotinic acid as a green and reusable catalyst. J. Mol. Struct. 2019, 1177, 525-535. [CrossRef]

28. Gujjarappa, R.; Vodnala, N.; Reddy, V.G.; Malakar, C.C. Niacin as a Potent Organocatalyst towards the Synthesis of Quinazolines using Nitriles as C-N Source. Eur. J. Org. Chem. 2020, 2020, 803-814. [CrossRef]

29. Putta, V.P.R.K.; Gujjarappa, R.; Vodnala, N.; Gupta, R.; Pujar, P.P.; Malakar, C.C. The facile and efficient organocatalytic platform for accessing 1,2,4-selenadiazoles and thiadiazoles under aerobic conditions. Tetrahedron Lett. 2018, 59, 904-908. [CrossRef]

30. Davarpanah, J.; Elahi, S.; Rezaee, P. Synthesis and characterization of mesoporous silica green catalyst, functionalized with nicotinic acid and its use for synthesis of pyran heterocyclic compounds. J. Porous Mat. 2018, 25, 161-170. [CrossRef]

31. Afradi, M.; Pour, S.A.; Dolat, M.; Yazdani-Elah-Abadi, A. Nanomagnetically modified vitamin $\mathrm{B}_{3}\left(\mathrm{Fe}_{3} \mathrm{O}_{4} @ \mathrm{Niacin}\right.$ : An efficient and reusable green biocatalyst for microwave-assisted rapid synthesis of 2-amino-3-cyanopyridines in aqueous medium: $\mathrm{Fe}_{3} \mathrm{O}_{4} @$ Niacin catalyzed synthesis of 2-amino-3-cyanopyridines. Appl. Organomet. Chem. 2018, 32, e4103. [CrossRef]

32. Radlowski, C.A.; Malick, G.M.; Miedona, C.T. Method of Making Hydroprocessing Catalyst. EP Patent 2823886, 14 August 2019.

33. Chuck, R. A Catalytic Green Process for the Production of Niacin. ChemInform 2000, 54, 508-513.

34. Mueller, M.B. Process for Preparing Pyridine Carboxylic Acids. U.S. Patent 2586555, 19 February 1952.

35. Black, G.; Deep, E.; Corson, B.B. Oxidation of Certain Methylpyridines to Pyridine Carboxylic Acids. J. Org. Chem. 1949, 14, 14-21. [CrossRef]

36. Woodward, C.F.; Badgett, C.O.; Kaufman, J.G. Chemical-Catalytic Liquid-Phase Oxidation of Nicotine $\beta$-picoline and Quinoline to Nicotinic Acid. Ind. Eng. Chem. 1939, 36, 544-546. [CrossRef]

37. Skowroń, J.; Konieczko, K. Occupational exposure to chromium(VI) compounds. Med. Pr. 2015, 66, 407-427. [CrossRef] [PubMed]

38. Zhou, P.P.; Sun, X.B.; Qiu, W.Y. Nicotinic Acid and Its Derivatives: Synthetic Routes, Crystal Forms and Polymorphs. Curr. Drug Discov. Technol. 2014, 11, 97-108. [CrossRef] [PubMed]

39. Biswell, C.B.; Wirth, W.V. Oxidation of Alkyl Pyridines and Alkyl Quinolines. U.S. Patent 2109954, 1 March 1938.

40. Shimizu, S.; Watanabe, N.; Kataoka, T.; Shoji, T.; Abe, N.; Morishita, S.; Ichimura, H. Pyridine and Pyridine Derivatives In Ullmann's Encyclopedia of Industrial Chemistry, 6th ed.; Wiley-VCH: Weinheim, Germany, 2012; pp. 1-34.

41. Chuck, R. Technology development in nicotinate production. Appl. Cat. A-Gen. 2005, 280, 75-82. [CrossRef]

42. Eschenmoser, W. 100 Years of Progress with LONZA. CHIMIA Int. J. Chem. 1997, 51, 259-269.

43. Stocker, A.; Pfammatter, T.; Schreiner, G.; Marti, O. Process for the Production of Pyridine Carboxylic Acids. U.S. Patent 3657259, 18 April 1972.

44. Van Arnum, S.D. Niacin, Nicotinamide, and Nicotinic Acids In Kirk-Othmer Encyclopedia of Chemical Technology, 4th ed.; John Wiley \& Sons, Inc.: Hoboken, NJ, USA, 2000; pp. 1-17.

45. Shaw, N.M.; Robins, K.T.; Kiener, A. Lonza: 20 Years of Biotransformations. Adv. Synth. Catal. 2003, 345, 425-435. [CrossRef]

46. Moulin, F.; Boosen, K.-J. Process for the Production of Cyanopyridines. U.S. Patent 4001255, 4 January 1977.

47. Takeishi, M.; Fujii, J.; Matsui, T. JP Patent 45013572, 15 May 1970.

48. Shimzu, S.; Shoji, T.; Abe, N.; Doba, M.; Taguro, A.; Iguchi, A.; Nakaishi, T. Process for Preparing Nitriles. U.S. Patent 4778890, 18 October 1988 
49. Inoue, A.; Ikeda, M.; Sano, K.; Terui, S.; Kanzaki, T. Process for Producing Aromatic Nitriles or Heterocyclic Nitriles. EP Patent 290996, 17 November 1988

50. Beschke, H.; Friedrich, H.; Helios, J. Catalysts for the Preparation of 3-Cyanopyridine. EP Patent 0059414, 8 September 1982.

51. Kumar, S.; Babu, B.V. Process Intensification of Nicotinic Acid Production via Enzymatic Conversion using Reactive Extraction. Chem. Biochem. Eng. Q. 2009, 23, 367-376. [CrossRef]

52. Cislak, F.E.; Wheeler, W.R. Piridinecarboxylic Acid Manufacture. CA Patent 427240, 1 May 1945.

53. Hatanaka, M.; Tanaka, N. Oxidative Ammonolysis of Alkylpyridines. WO Patent 9305022, 18 March 1993.

54. Asatsuka, Y.; Takikawa, I.H.S. Preparation of Niacin. CN Patent 1112921, 6 December 1995.

55. Hashimoto, T.; Nakamura, K.; Takagawa, M. Process for the Production of Pyridinecarboxylic Acids. U.S. Patent 5700944, 23 December 1997.

56. Ishii, Y.; Nakano, T.; Hirai, N. Method for Producing Carboxylic Acid. JP Patent 2001253838, 18 September 2001.

57. Hamano, M.; Nagy, K.D.; Jensen, K.F. Continuous flow metal-free oxidation of picolines using air. Chem. Commun. 2012, 48, 2086-2088. [CrossRef]

58. Barry, T.W.; Keith, W.; Cepeda, G.-B.E.; Poliakoff, M.; Hamley, P.A. Process for Producing Heteroaromatic Carboxylic Acids. US Patent 7560566, 14 July 2009.

59. Fraga-Dubreuil, J.; Garcia-Verdugo, E.; Hamley, P.A.; Vaquero, E.M.; Dudd, L.M.; Pearson, I.; Housley, D.; Partenheimer, W.; Thomas, W.B.; Whiston, K.; et al. Catalytic selective partial oxidations using $\mathrm{O}_{2}$ in supercritical water: The continuous synthesis of carboxylic acids. Green Chem. 2007, 9, 1238-1245. [CrossRef]

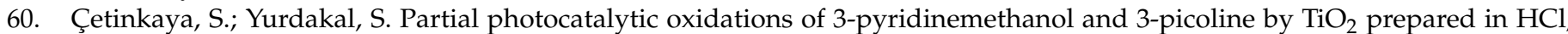
$\mathrm{HNO}_{3}$ and $\mathrm{H}_{2} \mathrm{SO}_{4}$ at different temperatures. Catal. Today 2021, 380, 237-247. [CrossRef]

61. Ghosh, S.; Acharyya, S.S.; Sharma, S.K.; Bal, R. Fabrication of Ag/ $\mathrm{Mn}_{3} \mathrm{O}_{4}$ nano-architectures for the onestep selective oxidation of 3-picoline to niacin: A key to vitamin $B_{3}$ production. Catal. Sci. Technol. 2016, 6, 44-46. [CrossRef]

62. Rajib, S.; Govindasamy, S. Selective oxidation of alkylarenes to aromatic acids/ketone in water by using reusable binaphthyl stabilized Pt nanoparticles (Pt-BNP) as catalyst. Appl. Catal. B-Environ. 2019, 250, 325-336. [CrossRef]

63. Adams, R.D.; Chen, M.; Elpitiya, G.; Potter, M.E.; Raja, R. Iridium-Bismuth Cluster Complexes Yield Bimetallic Nano-Catalysts for the Direct Oxidation of 3-Picoline to Niacin. ACS Catal. 2013, 3, 3106-3110. [CrossRef]

64. Singh, S.K.; Tiwari, N.; Agarwal, A. Process for Producing Piridinecarboxylic Acids. U.S. Patent 2012065405, 15 March 2012.

65. Alkaeva, E.M.; Andrushkevich, T.V.; Zenkovets, G.A.; Makarenko, M.G. Method of Obtaining Nicotinic Acid. U.S. Patent 5728837, 17 March 1998.

66. Ovchinnikova, E.V.; Chumachenko, V.A.; Vernikovskaya, N.V.; Kashkin, V.N.; Andrushkevich, T.V. A Study of Nicotinic Acid Synthesis on a Pilot Installation and Its Simulation. Russ. J. Appl. Chem. 2010, 83, 846-853. [CrossRef]

67. Chuck, R.; Zacher, U. Process for the Preparation of Nicotinic Acid. U.S. Patent 6376677, 23 April 2002.

68. Andrushkevich, T.V.; Ovchinnikova, E.V. Gas Phase Catalytic Oxidation of $\beta$ - Picoline to Nicotinic Acid: Catalysts, Mechanism and Reaction Kinetics. Catal. Rev. 2012, 54, 399-436. [CrossRef]

69. Vorobyev, P.B.; Saurambaeva, L.I.; Mikhailovskaya, T.P. Oxidation of 3- and 4-Methylpyridines on Modified Vanadium Oxide Catalysts. Russ. J. Gen. Chem. 2013, 83, 972-978. [CrossRef]

70. Vorobyev, P.; Mikhailovskaya, T.; Yugay, O.; Saurambaeva, L.; Serebryanskaya, A.; Chukhno, N.; Kurmakyzy, R. Optimization of vanadium oxide catalyst for the oxidation of 3-methylpyridine into nicotinic acid. J. Serb. Chem. Soc. 2017, 82, 791-801. [CrossRef]

71. Tabanelli, T.; Mari, M.; Folco, F.; Tanganelli, F.; Puzzo, F.; Setti, L.; Cavani, F. Reactivity of vanadyl pyrophosphate catalyst in ethanol ammoxidation and $\beta$-picoline oxidation: Advantages and limitations of bi-functionality. Appl. Catal. A-Gen. 2021, 619, 118-139. [CrossRef]

72. Alkayeva, Y.; Gibadullin, R.; Merakhovich, M.; Abdurakhmanov, A.; Holubyeva, A.; Shutilov, A.; Zenkovets, G. Microwave assisted heterogeneous vapor-phase oxidation of 3-picoline to nicotinic acid over vanadium-titanium oxide catalytic system. Appl. Catal. A-Gen. 2015, 491, 1-7. [CrossRef]

73. Goto, Y.; Shimizu, K.; Murayama, T.; Uedad, W. Hydrothermal synthesis of microporous W-V-O as an efficientcatalyst for ammoxidation of 3-picoline. Appl. Catal. A-Gen. 2016, 509, 118-122. [CrossRef]

74. Cao, W.; Kattau, R.A.; Kreilis, G. Continuous Processes for the Hydrolysis of Cyanopyridines under Substantially Adiabatic Conditions. U.S. Patent 5756750, 26 May 1998.

75. Moeller, A.; Friedrich, H.; Kuhn, H.; Winkler, K. Method of Producing-Coarse Crystalline Nicotinic Acid with a High Degree of Purity. U.S. Patent 4959478, 25 September 1990.

76. Finkelstein, E. Process for Separating an Acid from an Amide. U.S. Patent 3678060, 18 July 1972.

77. Fuhai, G.; Xiaolu, Y.; Min, L.; Canping, W. Preparation Method of High Purity Nicotinamide and Nicotinic Acid. CN Patent 104496894, 8 April 2015.

78. Mathew, C.D.; Nagasawa, T.T.; Yamada, H.; Kobayashi, M. Nitrilase-catalyzed production of nicotinic acid from 3-cyanopyridine in Rhodococcus rhodochrous. Appl. Environ. Microbiol. 1988, 54, 1030. [CrossRef] [PubMed]

79. Vaughan, P.A.; Knowles, C.J.; Cheetham, P.S.J. Conversion of 3-cyanopyridine to nicotinic acid by Nocardia rhodochrous LL100-21. Enzyme Microb. Technol. 1989, 11, 815-823. [CrossRef]

80. Qadreyah, A.A.; Don, A.C. Thermostable nitrilase catalysed production of nicotinic acid from 3-cyanopyridine. Enzyme Microb. Technol. 1999, 25, 718. [CrossRef] 
81. Cantarella, M.; Cantarella, L.; Gallifuoco, A.; Intellini, R.; Kaplan, O.; Spera, A.; Martınkova, L. Amidase-catalyzed production of nicotinic acid in batch and continuous stirred membrane reactors. Enzyme Microb. Technol. 2008, 42, 222-229. [CrossRef]

82. Li, C.; Wang, G.; Feng, H.; He, T.; Wang, Y.; Xu, T. Cleaner production of Niacin using bipolar membranes electrodialysis (BMED). Sep. Purif. Technol. 2015, 156, 391-395. [CrossRef]

83. Raja, R.; Adams, R.D.; Blom, D.A.; Pearl, W.C., Jr.; Gianotti, E.; Thomas, J.M. New Catalytic Liquid-Phase Ammoxidation Approach to the Preparation of Niacin (Vitamin $B_{3}$ ). Langmuir 2009, 25, 7200-7204. [CrossRef]

84. Suvorov, B.V.; Stepanova, L.A.; Belova, N.A.; Chuck, R.; Pianzola, D. Oxidative Ammonolysis of Alkylpyridines. WO Patent 9532054, 30 November 1995.

85. Ryoji, I.; Norio, K.; Kuniomi, M. Process for the Preparation of 3-Cyanopyridine. U.S. Patent 3959297, 25 May 1976.

86. Thomas, A.M.J.; Van Den Brink, F.; Van Hardeveld, R. Process for the Electrochemical Oxidation of Organic Products. EP Patent 0253439, 20 January 1988.

87. Toomey, J.E., Jr. Electrochemical Synthesis of Niacin and Other N-Heterocyclic Compounds. U.S. Patent 5002641, 26 March 1991.

88. Lisicki, D.; Maciej, A.; Orlińska, B. Selective Aerobic Oxidation of Toluene in the Presence of $\mathrm{Co}^{2+}$ and Task-Specific Organic Salts, Including Ionic Liquids. Ind. Eng. Chem. Res. 2021, 60, 11579-11589. [CrossRef] 